\title{
Analisis Kesalahan Siswa dalam Menyelesaikan Soal Logaritma Menggunakan Tahapan Kesalahan Kastolan
}

\author{
Desnani Ulfa ${ }^{1}$, Kartini Kartini ${ }^{2}$ \\ 1, 2 Program Pascasarjana Pendidikan Matematika, Fakultas Keguruan dan Ilmu Pendidikan, Universitas Riau, \\ Jl. Bina Widya KM. 12,5, Pekanbaru, Indonesia \\ desnaniulfa@gmail.com
}

\begin{abstract}
This research is motivated by the number of students who make mistakes in answer the question, so that it can be a clue to find out how far students have mastered the material. The logarithmic material was chosen for this study because logarithms have properties that must be understood by students so that they can easily find mistakes made by students. The purpose of this study was to analyze students' errors in solving logarithmic problems. The research subjects were class X MIPA 2 as many as 21 people at SMAN 1 Bangkinang Kota for the 2020/2021 school year. This research method is descriptive qualitative. The analysis was carried out by giving a written test of 5 items. The question analysis used the Kastolan error stage consisting of conceptual errors, procedural errors, and technical errors. The results showed that the percentage of errors most often made by students, namely $38.1 \%$, occurred in the procedural errors. This is indicated by the student still not mastering every step in the completion to the final completion or in its simplest form.
\end{abstract}

Keywords: Error Analysis, Kastolan, Logarithm.

\begin{abstract}
Abstrak
Penelitian ini dilatarbelakangi oleh banyaknya siswa yang melakukan kesalahan dalam menjawab soal, sehingga dapat menjadi petunjuk untuk mengetahui seberapa jauh siswa menguasai materi Materi logaritma dipilih untuk penelitian ini karena logaritma memiliki sifat-sifat yang harus dipahami oleh siswa sehingga dapat dengan mudah menemukan kesalahan yang dilakukan siswa. Tujuan penelitian ini untuk menganalisis kesalahan siswa dalam menyelesaikan soal logaritma. Subjek penelitian adalah kelas X MIPA 2 sebanyak 21 orang di SMAN 1 Bangkinang Kota tahun pelajaran 2020/2021. Metode penelitian ini adalah kualitatif deskriptif. Analisis dilakukan dengan memberikan tes tertulis sebanyak 5 butir soal. Analisis soal menggunakan tahapan kesalahan Kastolan yang terdiri dari kesalahan konseptual, kesalahan prosedural, dan kesalahan teknik. Hasil penelitian menujukkan bahwa persentase kesalahan yang paling banyak dilakukan siswa yakni $38,1 \%$ terjadi pada jenis kesalahan prosedural. Hal ini ditandai dengan siswa masih belum menguasai setiap langkah-langkah dalam penyelesaian hingga ke penyelesaian akhir atau dalam bentuk paling sederhana.
\end{abstract}

Kata kunci: Kata kunci: Analisis Kesalahan, Kastolan, Logaritma.

Copyright (c) 2021 Desnani Ulfa, Kartini Kartini

$\triangle$ Corresponding author: Kartini

Email Address: kartini@ @ecturer.unri.ac.id (Kampus Bina Widya Km 12,5 Simpang Baru, Pekanbaru, Indonesia)

Received 02 Februari 2021, Accepted 16 Maret 2021, Published 17 Maret 2021

\section{PENDAHULUAN}

Matematika merupakan sumber ilmu dari yang lain. Terdapat banyak ilmu yang penemuannya dan pengembangannya bergantung dari matematika. Semua masalah kehidupan yang membutuhkan pemecahan cermat dan teliti mau tidak mau harus berpaling kepada matematika (Danim, 2012). Matematika memiliki karakteristik yang berbeda dengan mata pelajaran lain, obyek matematika pada dasarnya adalah abstrak (Agnesti \& Amelia, 2020). Contoh keabstrakan matematika adanya simbol. Tidak sedikit siswa yang mengalami kesulitan belajar pada bidang yang banyak berkaitan dengan angka-angka ini (Hamidah et al., 2017). Kendalanya adalah matematika memiliki karakteristik yaitu mempunyai objek yang bersifat abstrak, sehingga dapat menyebabkan banyak siswa yang sulit terhadap belajar matematika dan siswa mengalami kesulitan ketika mengubah soal cerita menjadi model matematika (Atiqa \& Kusrini, 2013). Kesulitan belajar disebabkan karena adanya hambatan 
Analisis Kesalahan Siswa dalam Menyelesaikan Soal Logaritma Menggunakan Tahapan Kesalahan Kastolan, Desnani

dalam belajar sehingga tidak dapat mencapai tujuan dan dapat diatasi dengan usaha yang lebih giat (Mulyadi, 2010).

Setiap siswa tidak dapat menghindari kesulitan dalam belajar matematika di sekolah, umumnya siswa mengalami tingkat kesulitan yang berbeda-beda dalam belajar matematika (Widodo, 2013). Siswa yang mengalami kesulitan memiliki peluang untuk dapat melakukan kesalahan dalam menyelesaikan soal matematika pada setiap pokok bahasan dalam pembelajaran (Untari, 2013).

Kesalahan adalah bentuk penyimpangan pada sesuatu hal yang telah dianggap benar atau bentuk penyimpangan terhadap sesuatu yang telah disepakati atau ditetapkan sebelumnya (Arya Wijaya \& Masriyah, 2013). Terdapat dua jenis kesalahan yaitu yang bersifat sistematis dan yang bersifat konsisten dipengaruhi oleh kompetensi siswa, sedangkan yang bersifat insidental tidak dipengaruhi oleh kompetensi siswa (Amir, 2015). Sedangkan analisis kesalahan adalah suatu upaya untuk mengamati, menemukan, dan mengklasifikasi kesalahan dengan aturan tertentu (Astuty \& Wijayanti, 2013).

Penelitian yang dilakukan oleh Pujilestari (2018) mengemukakan bahwa kesalahan yang dilakukan siswa adalah sebagai berikut: 1) Kesalahan konsep dilakukan oleh 24 siswa atau 25,26\%,2) Kesalahan konsep dilakukan oleh 41 siswa atau 43,15\%,3) Kesalahan perhitungan dilakukan oleh 21 siswa atau 22,10\%. Dari hal tersebut dapat dikatakan pemahaman konsep penting untuk belajar matematika secara bermakna, tentunya para guru mengharapkan pemahaman yang dicapai siswa tidak terbatas pada pemahaman yang bersifat dapat menghubungkan (Murizal et al., 2012).

Kesulitan siswa dalam mengerjakan soal disebabkan oleh berbagai macam faktor, baik faktor dari dalam diri maupun faktor dari luar diri (Jamal, 2014). Faktor dari dalam diri dapat berupa kurangnya motivasi, kurang minat siswa terhadap materi tersebut, bakat siswa tidak dalam pelajaran matematika, pola pikir siswa sudah menganggap matematika itu sulit dan lain sebagainya (Raharti \& Yunianta, 2020). Faktor dari luar diri biasanya kondisi lingkungan belajar, teman yang malas, dukungan keluarga dan lainnya (Layn \& Kahar, 2017). Siswa yang melakukan kesalahan dalam mengerjakan soal juga dapat menjadi petunjuk untuk mengetahui seberapa jauh siswa menguasai materi. Kesulitan-kesulitan yang dialami siswa dapat terjadi karena siswa kurang menguasai konsep logaritma (Pawestri et al., 2013). Materi logaritma dipilih untuk penelitian ini karena logaritma memiliki sifat-sifat yang harus dipahami oleh siswa sehingga dapat dengan mudah menemukan kesalahan yang dilakukan siswa. Materi logaritma ini baru diajarkan di kelas X SMA tidak pernah diajarkan di SMP sehingga siswa baru mengenal materi logaritma. Tidak paham akan sifat logaritma termasuk kedalam ketidakpahaman konsep. Dalam satu soal logaritma harus dikerjakan dengan minimal satu sifat, pada kebanyakan soal logaritma diselesaikan dengan lebih dari satu sifat.

Berdasarkan permasalahan tersebut, diperlukan penelitian analisis terhadap kesalahan yang dilakukan siswa untuk menghindari munculnya kesalahan yang sama dilain waktu dalam menyelesaikan soal logaritma. Analisis kesalahan yang digunakan adalah kesalahan Kastolan. 
Terdapat 3 jenis kesalahan menurut Kastolan, yaitu kesalahan konseptual, kesalahan prosedural, dan kesalahan teknik (Muslimatul Khanifah \& Nusantara, 2013).

Penelitian terdahulu yang menggunakan tahapan Kastolan dilakukan oleh Florencia Ivani Hananta \& Ratu (2019) dengan subjek 3 orang dan Supita et al (2020) dengan subjek 35 subjek diambil 5 sampel dikelompokkan dengan kriteria kemampuan awal tinggi dan kemampuan awal rendah, sedangkan penelitian ini dilakukan dengan 21 subjek disertai persentase dari tiap- tiap kesalahan Kastolan. Tujuan dari penelitian ini adalah untuk mengetahui jenis kesalahan yang dilakukan siswa kelas X SMA Negeri 1 Bangkinang Kota beserta persentase dari tiap kesalahan dalam menyelesaiakan soal matematika pada materi logaritma dengan menggunakan tahapan kesalahan Kastolan.

\section{METODE}

Penelitian ini adalah penelitian deskriptif kualitatif untuk meneliti kesalahan yang dilakukan siswa dalam menyelesaikan soal logaritma. Subjek penelitian adalah kelas X MIPA 2 yang berjumlah 21 orang dengan teknik pengambilan sampel adalah purposive sampling. Analisis kesalahan yang digunakan dalam penelitian ini menggunakan tahapan kesalahan Kastolan. Dalam mengidentifikasi kesalahan-kesalahan yang dilakukan oleh siswa dilakukan dengan melihat langkah-langkah penyelesaian. Sehingga dibutuhkan indikator-indikator yang digunakan untuk mempermudah indentifikasi kesalahan tersebut. Indikator-indikator kesalahan yang peneliti buat sesuai dengan analisis Kastolan. Indikator-indikator tersebut disajikan dalam tabel 1 berikut:

Tabel 1. Indikator Kesalahan Kastolan

\begin{tabular}{|c|c|c|}
\hline No & Jenis Kesalahan & Indikator Kesalahan \\
\hline 1 & Kesalahan Konseptual & $\begin{array}{l}\text { - Tidak dapat menafsirkan soal/menggunakan suatu } \\
\text { istilah, konsep, dan prinsip } \\
\text { - Tidak dapat memilih rumus/sifat logaritma } \\
\text { dengan benar } \\
\text { - Tidak dapat menerapkan rumus/sifat logaritma } \\
\text { tersebut dengan benar }\end{array}$ \\
\hline 2 & Kesalahan Prosedural & $\begin{array}{l}\text { - Ketidaksesuaian langkah dalam penyelesaian soal } \\
\text { yang diperintahkan } \\
\text { - Tidak dapat menyelesaikan soal sampai pada } \\
\text { bentuk paling sederhana. }\end{array}$ \\
\hline 3 & Kesalahan Teknik & $\begin{array}{l}\text { - Melakukan kesalahan dalam operasi hitung } \\
\text { - Melakukan kesalahan dalam memindahkan angka } \\
\text { atau operasi hitung dari satu langkah ke langkah } \\
\text { berikutnya }\end{array}$ \\
\hline
\end{tabular}

(Dimodifikasi dari Kastolan)

Teknik yang digunakan dalam mengumpulkan data pada penelitian ini terdiri dari: 1) Tes tertulis dilaksanakan pada saat penelitian dengan memberikan soal berbentuk uraian kepada siswa setelah sebelumnya mendapatkan materi logaritma, 2) Dokumentasi hasil jawaban siswa. Teknik analisis data 
Analisis Kesalahan Siswa dalam Menyelesaikan Soal Logaritma Menggunakan Tahapan Kesalahan Kastolan, Desnani Ulfa, Kartini Kartini

terdiri dari 3 komponen, yaitu reduksi data, penyajian data, dan penarikan kesimpunan (Mahfud et al., 2015). Sebelum soal diberikan, terlebih dahulu soal diuji coba ke kelas yang bukan merupakan kelas penelitian bertujuan untuk mengetahui apakah instrumen yang digunakan memenuhi kriteria layak/tidak. Soal yang digunakan dalam penelitian sebagai berikut:

Soal:

1. Ubahlah bentuk eksponen $5^{3}=125$ ke bentuk logaritma!

2. Tentukan nilai dari

${ }^{3} \log 54+{ }^{3} \log 2-{ }^{3} \log 4-{ }^{3} \log 9$

3. Hitunglah nilai dari $\sqrt{3} \log \frac{1}{27}$ !

4. Misalkan ${ }^{3} \log 2=\mathrm{x}$. Nyatakan bentuk ${ }^{3} \log 6$ dalam bentuk $\mathrm{x}$ !

5. Agar udara menjadi bersih siswa SMA GO GREEN menanam beberapa pohon mangga di halaman sekolah. Setelah diamati, tinggi pohon setelah $t$ hari adalah $\mathrm{h}(\mathrm{t})={ }^{6} \log (\mathrm{t}+2)$ meter. Jika ${ }^{3} \log 2=\mathrm{x}$ dan ${ }^{2} \log 5=\mathrm{y}$, maka tinggi mangga setelah 88 hari adalah ... meter

Gambar 1. Soal Penelitian

Instrumen soal akan diujikan menggunakan uji validitas, reliabilitas, daya beda, dan tingkat kesukaran.

\section{HASIL DAN DISKUSI}

Berdasarkan hasil analisis pengolahan data akhir diperoleh kesalahan-kesalahan yang dilakukan siswa dalam penyelesaian soal logaritma. Soal dianalisis menggunakan klasifikasi kesalahan Kastolan dengan berpatokan pada indikator kesalahan. Adapun hasil analisis data yang dialami oleh siswa sebagai berikut beserta rata-rata persentase tiap kesalahan:

\section{Kesalahan Konseptual}

Kesalahan konseptual adalah kesalahan dalam menafsirkan ataupun menggunakan suatu istilah, konsep, dan prinsip, Kastolan dalam (Sahriah et al., 2012) . Adapun rata-rata persentase kesalahan konseptual dapat dilihat pada tabel 2 berikut:

Tabel 2. Rata-rata Persentase Kesalahan Konseptual

\begin{tabular}{|c|c|c|}
\hline No Soal & Jumlah Siswa & Persentase (\%) \\
\hline 1 & 1 & $4,8 \%$ \\
\hline 2 & 1 & $4,8 \%$ \\
\hline 3 & 3 & $14,3 \%$ \\
\hline 4 & 0 & $0 \%$ \\
\hline 5 & 2 & $9,5 \%$ \\
\hline Rata-rata & \multicolumn{2}{|c|}{$6,7 \%$} \\
\hline
\end{tabular}

Tabel. 2 memperlihatkan bahwa kesalahan konseptual dilakukan siswa pada soal nomor 1, 2, 3, dan 5. Berikut salah satu jawaban siswa yang melakukan kesalahan konseptual: 


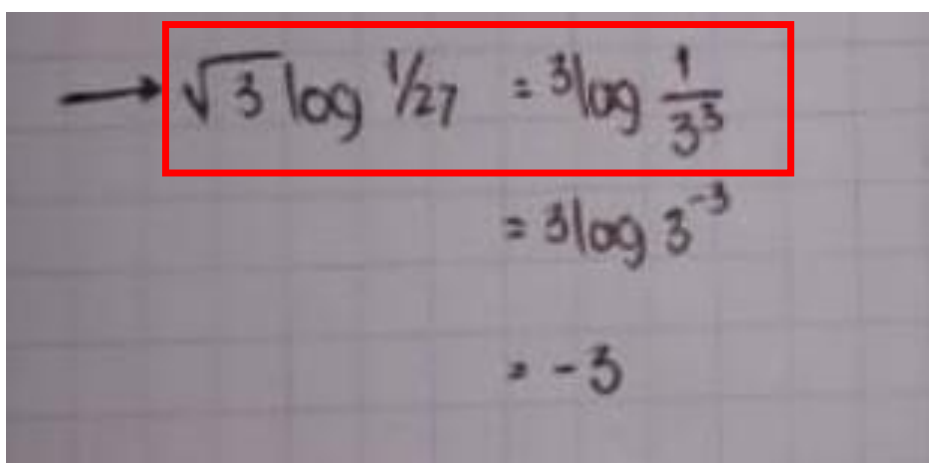

Gambar 2. Jawaban Siswa Soal Nomor 3

Pada gambar 2 siswa melakukan kesalahan dalam menafsirkan simbol matematika yang terdapat pada salah indikator kesalahan konseptual yaitu tidak dapat menafsirkan soal/menggunakan suatu istilah, konsep, dan prinsip. Hal ini ditandai dengan kurangnya pengetahuan siswa dalam mengetahui bentuk lain dari simbol matematika yang mengakibatkan terjadinya kesalahan saat melakukan operasi hitung, pada soal tertera $\sqrt{3} \log \frac{1}{27}$ bentuk lain dari $\sqrt{3}$ seharusnya menjadi $3^{\frac{1}{2}}$, akan tetapi siswa hanya menuliskan $3 \log \frac{1}{3^{3}}$ menghilangkan bentuk akar $(\sqrt{ })$ dari penyelesaian sehingga jawaban yang didapat tidak tepat.

\section{Kesalahan Prosedural}

Kesalahan prosedural adalah kesalahan dalam upaya mneyusun langkah-langkah yang hirarkis dan sistematis untuk menjawab suatu permasalahan, Kastolan dalam (Sahriah et al., 2012). Adapun rata-rata persentase kesalahan prosedural dapat dilihat pada tabel 3 berikut:

Tabel 3. Rata-rata Persentase Kesalahan Prosedural

\begin{tabular}{|c|c|c|}
\hline No Soal & Jumlah Siswa & Persentase (\%) \\
\hline 1 & 0 & $0 \%$ \\
\hline 2 & 1 & $4,8 \%$ \\
\hline 3 & 2 & $9,5 \%$ \\
\hline 4 & 2 & $9,5 \%$ \\
\hline 5 & 3 & $14,3 \%$ \\
\hline Rata-rata & \multicolumn{2}{|c|}{$7,6 \%$} \\
\hline
\end{tabular}

Tabel. 3 memperlihatkan bahwa kesalahan konseptual dilakukan siswa pada soal nomor 2, 3, 4, dan 5. Berikut salah satu jawaban siswa yang melakukan kesalahan prosedural dapat dilihat pada gambar 3. Pada gambar 3 siswa berhenti dan tidak dapat melanjutkan penyelesaian jawaban yang terdapat pada salah satu indikator kesalahan prosedural yaitu tidak dapat menyelesaikan soal sampai pada bentuk paling sederhana. Hal ini ditandai dengan kurangnya siswa dalam memahami sifat-sifat logaritma yang ada. Siswa tidak dapat mengubah bentuk dari $2 \log 3^{2}$, bentuk tersebut dapat diselesaikan dengan menjabarkan $22_{\log 3^{2}}=22_{\log 3}$ sehingga tidak dapat menyelesaikan soal sampai pada bentuk paling sederhana terhenti ditengah penyelesaian padahal langkah demi langkah yang dilakukan siswa telah tepat/benar 

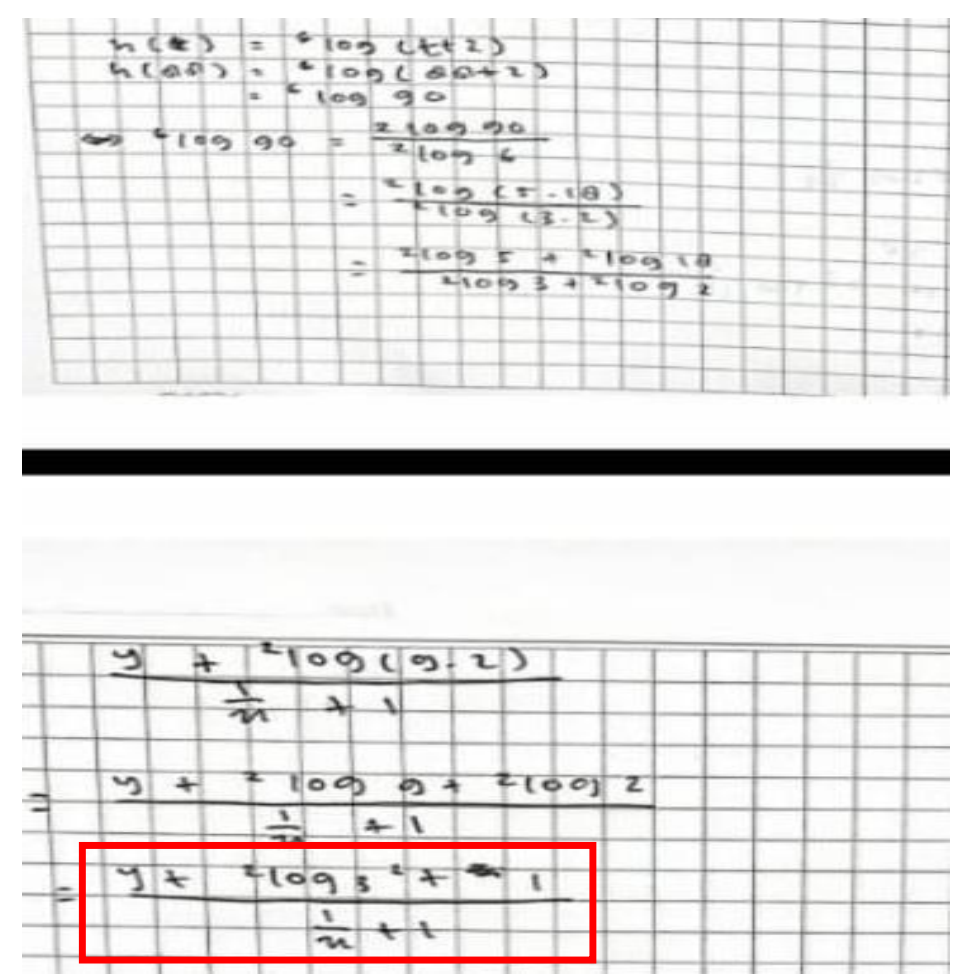

Gambar 3. Jawaban Siswa Soal Nomor 5

\section{Kesalahan Teknik}

Kesalahan teknik adalah kesalahan yang disebabkan adanya kesalahan perhitungan, Kastolan dalam (Lutfia \& Sylviana Zanthy, 2019) . Adapun rata-rata persentase kesalahan teknik dapat dilihat pada tabel 4 berikut:

Tabel 4. Rata-rata Persentase Kesalahan Teknik

\begin{tabular}{|c|c|c|}
\hline No Soal & Jumlah Siswa & Persentase (\%) \\
\hline 1 & 0 & $0 \%$ \\
\hline 2 & 2 & $9,5 \%$ \\
\hline 3 & 0 & $0 \%$ \\
\hline 4 & 2 & $9,5 \%$ \\
\hline 5 & 1 & $4,8 \%$ \\
\hline Rata-rata & \multicolumn{2}{|c|}{$4,8 \%$} \\
\hline
\end{tabular}

Tabel. 4 memperlihatkan bahwa kesalahan konseptual dilakukan siswa pada soal nomor 2, 4, dan 5. Berikut salah satu jawaban siswa yang melakukan kesalahan teknik dapat dilihat pada gambar 4 . Pada gambar 4 siswa melakukan kesalahan saat memindahkan tanda operasi positif (+) dari persamaan yang terdapat pada salah satu indikator kesalahan teknik yaitu melakukan kesalahan dalam memindahkan angka atau operasi hitung dari satu langkah ke langkah berikutnya. Siswa menuliskan hasil dari $3_{\log 9}=3_{\log 27} \rightarrow 3_{\log 27}+3_{\log 9}$ seharusnya jawaban yang benar adalah $3_{\log 9}=$ $3_{\log 27} \rightarrow 3_{\log 27}-3_{\log 9}$ karena tanda operasi positif (+) dalam persamaan jika dipindahkan akan berubah menjadi negatif (-), dengan adanya kesalahan siswa ini dalam merubah operasi hitung saat penyelesaian mengakibatkan hasil akhir jawaban siswa tidak tepat. 


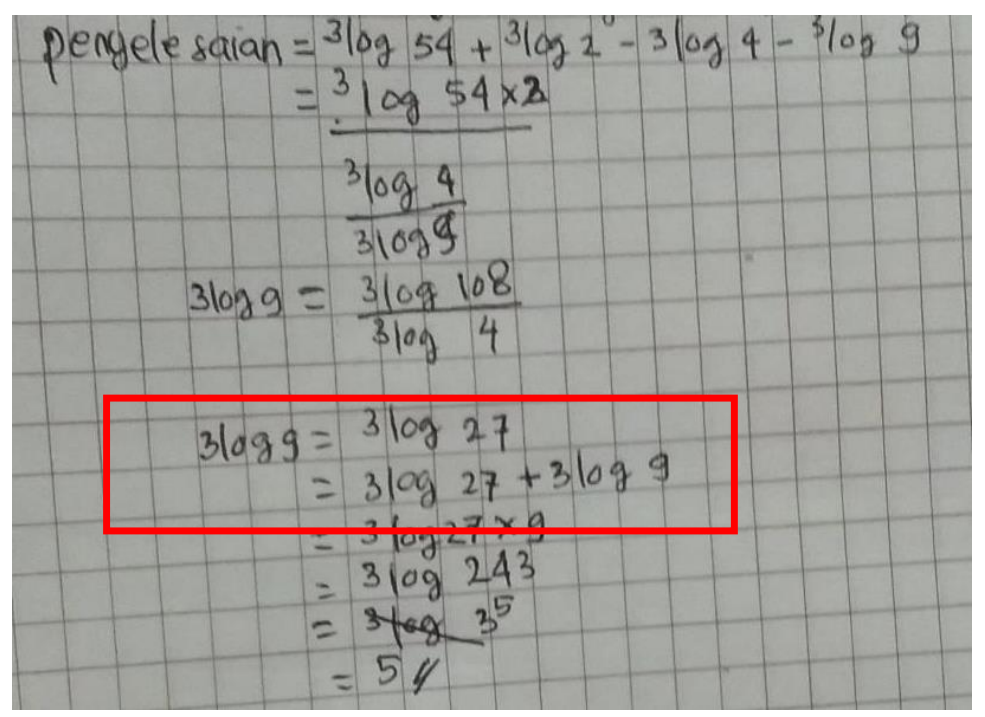

Gambar 4. Jawaban Siswa Soal Nomor 2

Berdasarkan hasil analisis soal yang dilakukan, dapat diketahui banyaknya siswa yang melakukan kesalahan menurut tahapan kesalahan Kastolan dapat dilihat perhitungan rata-rata persentasenya. Berikut tabel 5 rekapitulasi perhintungan persentase tiap kesalahan siswa:

Tabel 5. Rekapitulasi Persentase Tiap Kesalahan

\begin{tabular}{|l|c|c|c|c|c|c|}
\hline \multirow{2}{*}{$\begin{array}{c}\text { Jenis } \\
\text { Kesalahan }\end{array}$} & \multicolumn{5}{|c|}{ Banyak Siswa } & \multirow{2}{*}{ Persentase } \\
\cline { 2 - 6 } & Soal 1 & Soal 2 & Soal 3 & Soal 4 & Soal 5 & \\
\hline Konseptual & 1 & 1 & 3 & 0 & 2 & $33,3 \%$ \\
\hline Prosedural & 0 & 1 & 2 & 2 & 3 & $38,1 \%$ \\
\hline Teknik & 0 & 2 & 0 & 2 & 1 & $23,8 \%$ \\
\hline
\end{tabular}

Dari hasil perhitungan persentase tersebut didapatkan banyaknya siswa melakukan kesalahan pada jenis kesalahan prosedural sebanyak $38,1 \%$, ditandai dengan siswa masih belum menguasai setiap langkah-langkah dalam penyelesaian hingga ke penyelesaian akhir atau bentuk paling sederhana. Kemudian persentase kesalahan konseptual sebanyak 33,3\%, ditandai dengan kurangnya pengetahuan siswa dalam mengetahui bentuk lain dari simbol matematika yang mengakibatkan terjadinya kesalahan saat melakukan operasi hitung. Dan persentase kelasahan siswa terendah adalah kesalahan teknik sebanyak $23,8 \%$, ditandai dengan siswa melakukan kesalahan dalam memindahkan angka atau operasi hitung dari satu langkah ke langkah berikutnya.

Hasil penelitian ini sejalan dengan penelitian yang dilakukan oleh Lutfia \& Sylviana Zanthy (2019) yaitu persentase kesalahan tertinggi pada penelitiannya terjadi pada kesalahan prosedural sebanyak $27,2 \%$ dimana siswa kurang memahami konsep dalam pengerjaan soal. 
Analisis Kesalahan Siswa dalam Menyelesaikan Soal Logaritma Menggunakan Tahapan Kesalahan Kastolan, Desnani Ulfa, Kartini Kartini

\section{KESIMPULAN}

Berdasarkan hasil penelitian yang telah dilakukan di kelas X SMA Negeri 1 Bangkinang dapat disimpulkan bahwa siswa kelas X SMA Negeri 1 Bangkinang masih banyak yang melakukan kesalahan dalam menyelesaikan soal matematika. Adapaun jenis kesalahan yang dilakukan siswa adalah: 1) Kesalahan konseptual. Kesalahan konseptual yang dilakukan oleh siswa yaitu kesalahan dalam menggunakan sifat-sifat logaritma untuk menyelesaikan soal matematika. Persentase kesalahan konsep sebanyak 33,3\%. 2) Kesalahan prosedural. Kesalahan prosedural yang dilkukan siswa yaitu kesalahan dalam langkah-langkah atau algoritma untuk menyelesaikan soal matematika. Persentase kesalahan prosedural sebanyak 38,1\%. 3) Kesalahan teknik. Kesalahan teknik yaitu kesalahan siswa dalam menentukan hasil akhir, dan salah dalam melakukan pemindahan operasi hitung didalam persamaan. Persentase kesalahan teknik sebanyak 23,8\%.

\section{UCAPAN TERIMA KASIH}

Ucapan terimakasih kepada semua pihak yang telah membantu penelitian, terutama yang mendanai penelitian ini, serta dosen yang telah memberikan bimbingannya dalam menyusun artikel ini. Penelitian ini diharapkan dapat menjadi referensi bagi semua pembaca.

\section{REFERENSI}

Agnesti, Y., \& Amelia, R. (2020). Analisis Kesalahan Siswa Kelas VIII SMP Dalam Menyelesaikan Soal Cerita Pada Materi Perbandingan Ditinjau Dari Gender. Jurnal Cendekia: Jurnal Pendidikan Matematika, 4(1), 151-162.

Amir, M. F. (2015). Analisis Kesalahan Mahasiswa PGSD Universitas Muhammadiyah Sidoarjo Dalam Menyelesaikan Soal Pertidaksamaan Linier. Jurnal Edukasi, 1(2), 131-145.

Arya Wijaya, A., \& Masriyah. (2013). Analisis Kesalahan Siswa Dalam Menyelesaikan Soal Cerita Materi Sistem Linear Dua Variabel. MATHEdunesa, 2(1), 1-7.

Astuty, K. Y., \& Wijayanti, P. (2013). Analisis Kesalahan Siswa Kelas V Dalam Menyelesaikan Soal Matematika Pada Materi Pecahan Di SDN Medokan Semampir 1/259 Surabaya. MATHEdunesa, 2(3).

Atiqa, Y., \& Kusrini. (2013). Pengaruh Pembelajaran Matematika Realistik Terhadap Memori Siswa Pada Sub Materi Perbandingan Senilai Dan Beralik Nilai Di Kelas VII SMPN 5 Tuban. MATHEdunesa, 2(1), 1-7.

Danim, S. (2012). Pengembangan Profesi Guru. Jakarta: Kencana.

Florencia Ivani Hananta, O., \& Ratu, N. (2019). Analisis Kesalahan Siswa Dalam Menyelesaikan Soal Logaritma. Jurnal Pendidikan Matematika Indonesia, 4(1), 29-35.

Hamidah, D., Putri, R. I. I., \& Somakim, S. (2017). Eksplorasi Pemahaman Siswa pada Materi Perbandingan Senilai Menggunakan Konteks Cerita di SMP. Jurnal Riset Pendidikan Dan Inovasi Pembelajaran Matematika (JRPIPM), 1(1), 1-49. 
Jamal, F. (2014). Analisis Kesulitan Belajar Siswa Dalam Mata Pelajaran Matematika Pada Materi Peluang Kelas XI IPA SMA Muhammadiyah Meulaboh Johan Pahlawan. Jurnal MAJU: Jurnal Pendidikan Matematika, 1(1), 18-36.

Layn, M. R., \& Kahar, M. S. (2017). Analisis Kesalahan Siswa Dalam Menyelesaikan Soal Cerita Matematika. Jurnal Math Educator Nusantara (JMEN), 03(02), 59-145.

Lutfia, L., \& Sylviana Zanthy, L. (2019). Analisis Kesalahan Menurut Tahapan Kastolan Dan Pemberian Scaffolding Dalam Menyelesaikan Soal Sistem Persamaan Linear Dua Variabel. Journal On Education, 1(3), 396-404.

Mahfud, Mujib, A., Agus Kurniawan, M., \& Yunita, Y. (2015). Pembelajaran Pendidikan Agama Islam Berbasis Multietnik. Deepublish.

Mulyadi. (2010). Diagnosis Kesulitan Belajar. Yogyakarta: Nur Litera.

Murizal, A., Yarman, \& Yerizon. (2012). Pemahaman Konsep Matematis dan Model Pembelajaran Quantum Teaching. Jurnal Pendidikan Matematika, 1(1), 19-23.

Muslimatul Khanifah, N., \& Nusantara, T. (2013). Analisis Kesalahan Penyelesaian Soal Prosedural Bentuk Pangkat Bulat dan Scaffoldingnya. Program Studi Pendidikan Matematika, 1-14.

Pawestri, U., Soeyono, \& Kurniawati, I. (2013). Analisis Kesulitan Pembelajaran Matematika Dengan Pengantar Bahasa Inggris Pada Materi Pokok Bentuk Logaritma Kelas X IMERSI SMA Negeri Karangpandan Karanganyar 2012/2013. Jurnal Pendidikan Matematika Solusi, 1(1), 1-7.

Pujilestari. (2018). Analisis Kesalahan Siswa Dalam Menyelesaikan Soal Matematika Sma Materi Operasi Aljabar Bentuk Pangkat Dan Akar. JISIP: Jurnal Ilmu Sosial Dan Pendidikan, 2(1), 226-232.

Raharti, A. D., \& Yunianta, T. N. H. (2020). Identifikasi Kesalahan Matematika Siswa SMP Berdasarkan Tahapan Kastolan. Journal of Honai Math, 3(1), 77-100.

Sahriah, S., Muksar, M., \& Eni Lestari, T. (2012). Analisis Kesalahan Siswa Dalam Menyelesaikan Soal Matematika Materi Operasi Pecahan Bentuk Aljabar Kelas VIII SMP Negeri 2 Malang. Jurnal Online Universitas Negeri Malang, 1-10.

Supita, S., Nuryani, L. Z., \& Istiqomah, I. (2020). Analisis Kesalahan Menyelesaikan Soal Uraian Matematika Materi Logaritma Kelas X SMK. UNION: Jurnal Ilmiah Pendidikan Matematika, $8(1), 41-51$.

Untari, E. (2013). Diagnosis Kesulitan Belajar Pokok Bahasan Pecahan Pada Siswa Kelas V Sekolah Dasar. Media Prestasi Jurnal Ilmiah STKIP PGRI Ngawi, 13(1), 1-8.

Widodo, S. A. (2013). Analisis Kesalahan Dalam Pemecahan Masalah Divergensi Tipe Membuktikan Pada Mahasiswa Matematika. Jurnal Pendidikan Dan Pengajaran, 46(2), 106-113. 